Fikrah: Jurnal Ilmu Aqidah dan Studi Keagamaan

ISSN 2354-6147 EISSN 2476-9649

Tersedia online di: journal.stainkudus.ac.id/index.php/fikrah

DOI: 10.21043/fikrah.v6i1.2602

\title{
Sedekah Online Yusuf Mansur: Otoritas dan Bahasa Agama di Media Sosial
}

\author{
Mansur Hidayat \\ Institut Agama Islam Negeri Kudus, Indonesia \\ mansurhidayat.id@gmail.com
}

\begin{abstract}
Abstrak
Artikel ini menjelaskan otoritas agama di media sosial dengan mengeksplorasi pada dakwah sedekah online yang disampaikan Yusuf Mansur (YM) di media sosial. Riset ini bertujuan untuk mengetahui bagaimana YM mengkonstruksi otoritas dan bahasa agama di media sosial dalam kegiatan dakwah sedekahnya serta mempelajari sejauh mana otoritas YM diikuti oleh audiens. Selain itu, kajian juga berguna dalam memahami peran media sosial dalam kegiatan filantropi. Artikel ini mengacu pada etnografi online dan offline terhadap aktivitas yang berhubungan dengan sedekah online YM di media sosial. Hasil menunjukkan bahwa dakwah sedekah YM disampaikan pada lapisan otoritas: selfpresentation, switching code, dan textual reference. Ketiga hal tersebut berguna dalam menguatkan legitimasi pesan dakwah sedekah online YM serta sebagai upaya mempertahankan diri di media sosial. Sedangkan pesan dakwah lebih banyak dikomunikasikan dengan mengaitkan pada imbalan materi. Upaya tersebut dapat menguatkan keyakinan audiens dalam bersedekah, tetapi dengan ideologi yang berbeda memiliki kecenderungan selektif dalam menerima pesan.
\end{abstract}

Kata Kunci: Bahasa agama, media sosial, otoritas, sedekah online 


\begin{abstract}
The article explained religious authority in social media by exploring on online alms dakwah delivered by Yusuf Mansur (YM). The problems were how the online dakwah by Yusuf Mansur delivered through social media and how far online alms of Yusuf Mansur has the authority to be followed. The research purposed to find out the way YM constructs authority and language of religion on social media in alms dakwah and learn how far YM authority is followed by the audience. In addition, the study is used to understand the role of social media in philanthropy activities. The article referred to four months of online and offline ethnographic fieldwork toward activity related to YM online alms on social media. Results show that the YM alms dakwah was a focus on the layer of authority: self-presentation, switching code, and textual reference. These three things were useful to reinforce the legitimacy of message of YM online alms dakwah as well as efforts to keep the existence of social media. While the message of dakwah was communicated by linked on material rewards. These efforts were able to strengthen audience believe in alms, but the audience with a different ideology tend to selective in receiving messages.
\end{abstract}

Keywords: Authority, language of religion, online alms, social media

\title{
Pendahuluan
}

Selama tiga puluh tahun terakhir Islam telah memainkan peranannya sebagai kekuatan yang turut membentuk kondisi sosial dan politik di Indonesia dengan identitas simbolik maupun kolektifnya (Hasan, 2009). Salah satu bentuk vitalitas Islam adalah munculnya gerakan filantropi dalam masyarakat Islam. Gerakan ini menjadi salah satu bentuk Islam publik sebagai upaya sadar untuk menunjukkan perhatian masyarakat Islam terhadap dinamika sosial, ekonomi, politik, dan representasi pembaruan Islam di Indonesia (Latief, 2017). Kegiatan kedermawanan sosial (filantropi) mulai berkembang pesat dan terorganisir, serta menemukan momentum terutama saat Indonesia mengalami krisis ekonomi yang kemudian diikuti dengan krisis politik yang berujung pada tumbangnya rezim Orde Baru di bawah kepemimpinan Presiden Soeharto pada 1998. Pada saat yang sama, bencana alam seperti gempa bumi, kebakaran hutan, tanah longsor, dan tsunami terjadi secara beruntun di tanah air. Krisis ekonomi dan bencana di mana-manatelah mendorong kepedulian dan solidaritas sosial masyarakat untuk berperan aktif membantu sesama (Abidin, 2013).

Badan Pusat Statistik (BPS) pada Mei 2012 merilis bahwa dari 237,6 juta jiwa penduduk Indonesia, 87,1 persen adalah pemeluk agama Islam. Sedangkan hasil 
penelitian kerjasama antara Badan Amil Zakat Nasional (BAZNAS) dengan Institut Pertanian Bogor (IPB) yang didasarkan pada Produk Domestik Bruto (PDB) 2010 menunjukkan bahwa potensi zakat di Indonesia telah mencapai Rp. 217 triliun. Jika diekstrapolasikan dengan mempertimbangkan pertumbuhan ekonomi nasional pada tahun-tahun sesudahnya, maka potensi tersebut pada akhir 2015 mencapai Rp. 286 triliun (Baznas, 2016). Potensi dana filantropi ini tentu dapat bertambah lebih besar apabila bentuk filantropi Islam yang lainnya dimasukkan seperti halnya wakaf, infak, dan sedekah (Kepresidenan, n.d.). Hal ini sejalan dengan semakin banyaknya jumlah masyarakat kelas menengah serta penetrasi pengguna internet di Indonesia yang terus mengalami peningkatan pada tiap tahunnya. Hasil survei terbaru dari Asosiasi Penyelenggara Jasa Internet Indonesia (APJII) menunjukkan bahwa 132,7 juta masyarakat Indonesia telah terintegrasi dengan internet. Terjadi peningkatan jumlah yang signifikan dari survei di tahun sebelumnya. Sedangkan media sosial adalah jenis konten internet yang paling sering diakses ketimbang konten-konten lainnya oleh netizen. Data menunjukkan bahwa 97,4 persen, atau sekitar 129,2 juta penduduk Indonesia adalah pengguna aktif media sosial (APJII, 2016, hal. 22).

Media sosial merupakan bagian penting dalam kehidupan manusia saat ini. Dengan kehadiran media baru ini beberapa hal yang dahulu tidak mungkin menjadi sesuatu yang lumrah terjadi. Jejaring sosial menjadi sarana penting dalam membangun interaksi yang lebih intens antar seseorang dengan orang lain, atau bahkan antar kelompok. Selain itu, media sosial dengan beberapa kelebihannya juga menjadi media penting yang turut mempromosikan suatu kebaikan yang dapat menjangkau dan menjaring khalayak secara luas (Walters, 2017). Dengan kata lain, keterampilan bermedia sosial menjadi syarat penting yang harus diperhatikan dalam rangka efektivitas penyampaian dakwah termasuk di dalamnya tentang sedekah online. Saat kegiatan berbagi telah menjadi salah satu agenda penting bagi Muslim kelas menengah, penghimpun dana sedekah dituntut untuk lebih kreatif, elegan, serta dapat menggunakan keterampilan guna mengajak masyarakat agar turut dalam kegiatan sedekah melalui sedekah online. Salah satu daripada agamawan yang kini sering mendakwahkan tentang sedekah (termasuk di dalamnya lewat media online) adalah Yusuf Mansur (YM). Saat ini, media sosial utama yang rutin digunakan oleh YM dalam 
menyampaikan tema tentang sedekah online adalah Facebook dan Instagram (Mansur, 2017, 2017). Aktivitas YM di media sosial menjadi suatu hal yang penting dikaji sebagai upaya untuk mengetahui sejauh mana peran media sosial dalam kegiatan sedekah. Dengan demikian, kajian dalam artikel berfokus pada penggunaan media sosial dalam kegiatan filantropi.

\section{Metode}

Data pada artikel ini dikumpulkan melalui kajian online, kerja lapangan, dan juga melalui beberapa dokumen. Jejak online dilihat pada Facebook dan Instagram YM serta website yang berkaitan dengan media sosial, seperti situs pribadi YM dan lembaga filantropi miliknya yang relevan dengan tema kajian dan penggalian data tidak terbatas pada online. Bentuk konfirmasi offline dilakukan sebagai penguat data. Selain itu, juga menggunakan berbagai buku, artikel, tesis-tesis akademis dan juga laporan-laporan yang dapat diakses berkenaan dengan objek kajian.

Sumber utama data ada dua yaitu media online dan offline yang dilaksanakan selama empat bulan terakhir, yakni sejak Januari hingga April 2017. Pengkaji melakukan kunjungan serta pengamatan ke beberapa media sosial seperti akun Facebook dan Instagram YM yang berkaitan dengan penekanan pada aspek dakwah filantropi di media sosial, yang sebelumnya menjelaskan secara terbuka posisi sebagai peneliti, kemudian melakukan wawancara mendalam dan pembicaraan informal dengan para audiens YM, baik dengan wawancara tatap muka dan wawancara termediasi melalui gawai.

Dalam memilih informan, peneliti menggunakan teknik sampel acak (randomsampling) dan mewawancarai sebelas audiens YM secara online dan offline. Untuk menghindari bias, informan dibagi berdasarkan latar belakang sosial, usia, serta motif mengikuti media sosial YM. Model wawancara bertujuan untuk mengumpulkan informasi tentang aktivitas dakwah filantropi di media sosial. Hal ini dikarenakan aksi merupakan suatu proses yang makna-maknanya dikonstruksi melalui interaksi. Ditanyakan juga riwayat hidup para individu untuk mempelajari pengalaman mereka sebelum mengikuti YM di media sosial. Hal ini sangat penting dalam rangka mengeksplorasi komposisi sosial kelompok dan beberapa faktor yang mendorong 
audiens ikut terlibat dalam kegiatan sedekah. Sedangkan pada tahap validasi menggunakan triangulasi data atau triangulasi teori. Validasi data dengan menguji dan mengkonfirmasi antara data satu dengan data lainnya untuk kemudian saya sajikan dalam bentuk penjelasan naratif.

\section{Dakwah Sedekah}

Media sosial dalam perkembangannya telah memiliki peranan khusus yang ikut memengaruhi cara manusia berinteraksi. Untuk itu artikel ini membahas dakwah sedekah online YM yang dipraktikkan melalui media sosial milik YM (Facebook dan Instagram). Pemilihan kedua jejaring sosial tersebut didasarkan pada upaya memahami kaitannya antara bahasa teks dengan kehidupan nyata di masyarakat (konteks) dan seberapa berarti kedua media sosial berperan dalam kehidupan sosial (Barton, David, 2013, hal. 14). Selain itu, dalam survei yang dilakukan oleh Charities Aid Foundation pada tahun 2016 (CAF, n.d.) masyarakat Indonesia merupakan orang-orang dermawan dengan persentase nilai tertinggi kedua di dunia. Fakta ini menunjukkan bahwa hampir keseluruhan orang Indonesia tergolong memiliki kedermawanan yang tinggi. Riset lebih lanjut menemukan bahwa motif sumbangan yang diberikan oleh orang Indonesia berdasarkan pada dorongan keagamaan yang dianut sebesar 84 persen.

Persentase ini juga berada pada posisi puncak dari negara-negara lain di dunia yang menjadikan faktor agama sebagai alasan utama dalam mendermakan harta (Ipsos, 2017). Di samping itu, Islam merupakan agama yang memiliki tingkat kedermawanan tertinggi dibanding dengan agama lain, yakni sebanyak 61 persen, disusul agama Hindu sebanyak 33 persen, Kristen 24 persen dan Budha 20 persen (Jakarta, n.d.). Riset lebih lanjut mengungkapkan sebanyak 90 persen dari pendapatan organisasi keagamaan di Indonesia berasal dari dana filantropi yang berasal dari masyarakat sipil (Adelman, 2003, hal. 65-75). Informasi lain juga dapat diamati dari jumlah keberangkatan jutaan muslim Indonesia yang pergi menunaikan ibadah haji, jumlah keberangkatan haji Indonesia merupakan yang terbesar dari negara-negara lain, sedangkan dalam ibadah umrah jamaah Indonesia berada pada urutan ketiga tertinggi setelah Mesir dan Pakistan, dengan jumlah kunjungan umrah yang terus meningkat pada tiap tahunnya (Muslim, n.d.).

Salah satu survei publik yang pernah dilakukan oleh PIRAC dan The Center for Language and Culture, UIN Syarif Hidayatullah pada tahun 2001 dan 2003 bahwa 
secara umum sumbangan sedekah berada pada posisi tertinggi kedua setelah zakat fitrah. Hal ini menarik karena sedekah pada dasarnya merupakan jenis sumbangan yang bersifat sukarela, berbeda dengan zakat fitrah yang berkekuatan hukum wajib. Secara berurutan, persentase sumbangan tertinggi ditempati oleh zakat fitrah (98\%), sedekah (93,6\%), zakat mal (34,7\%), serta wakaf (22,8\%) (Fauzia, 2016, hal. 303). Secara istilah, sedekah (sadaqah) merupakan penyerahan harta kepada pihak yang membutuhkan (mustahiq) sesuai dengan kemampuan tanpa imbalan tertentu dengan tujuan karena Allah (Kemenag RI, 2014, hal. 164). Hukum dasar sedekah adalah sunnah muakkadah atau sunah yang dikuatkan pengamalannya (Azzam, Abdul Aziz Muhammad, 2010, hal. 423-424). Dengan dasar hukum QS. as-Saba':

"Dan barang apa saja yang kamu nafkahkan, maka Allah akan menggantinya dan Dia-lah pemberi rezeki yang sebaik-baiknya".

Maupun hadis,

"Jika manusia mati maka terputuslah amalnya kecuali yang tiga: shadaqah jariyah, ilmu yang bermanfaat, atau anak shalih yang mendoakannya." (Qardhawi, 2013, hal. 180).

Permulaan dakwah sedekah YM dapat diamati dari awal ketika ia terlilit hutang yang menyebabkannya masuk penjara dua kali, yakni pada 1996 dan 1998. Dikatakan bahwa sejak berada dalam penjara itulah YM mendapatkan hikmah yang menjadi titik balik dalam kehidupannya. YM berkesimpulan bahwa kejadian yang berhasil merubah jalan hidupnya tersebut tidak dapat dipisahkan dari praktik sedekah yang ia lakukan (Yayan, 2013, hal. 29-32). YM mulai dikenal luas oleh masyarakat tahun 2000-an melalui siaran salah satu program yang disampaikan melalui televisi swasta nasional, ANTV, selanjutnya melalui siaran yang secara rutin ditayangkan tiap hari pada pukul 05.00 WIB tersebut menjadikannya populer dengan sebutan "ustaz sedekah". Pada mulanya untuk menata pengelolaan dakwahnya, ia membentuk komunitas wisata hati dengan produk buku perdananya "Mencari Tuhan yang Hilang" yang terbit pada 2006. Produk berikutnya yang terbit dari komunitas tersebut adalah "Kun Faa Yaa Kun” yang kemudian difilmkan.

Berbarengan dengan program dakwah tersebut, YM melalui lembaga yang dibentuk mulai merintis pembangunan pesantren tahfiz yang memiliki tujuan utama 
melakukan kaderisasi penghafal al-Quran di seluruh Nusantara. Awal pesantren tersebut bermula dari usulan $\mathrm{H}$. Ahmad yang datang dan mengadukan perihal keadaan pesantren yang dikelolanya. Pesantren yang dipimpin tersebut membutuhkan donasi dari para donatur. Pada sore harinya yang bertepatan 5 Juli 2003, YM meminta pengelola pesantren tersebut untuk menempatkan beberapa orang santrinya di rumahnya. Tidak berselang lama, kemudian YM dan tim menemukan lokasi yang cocok sebagai pesantren untuk menampung para santri tersebut yang terletak di wilayah Bulak Santri yang letaknya berada di Pondok Pocung Kecamatan Karang Tengah, Ciledung, Tangerang, Banten.

Selanjutnya, pada 2005, YM melalui Yayasan Daarul Quran mendirikan SMP Islam Darul Quran agar para santri dapat belajar di dalam lingkungan pesantren. Jumlah siswa masuk di tahun pertama sebanyak delapan orang dan di tahun kedua sebanyak 20 santri. Inilah periode awal lahir dan berkembangnya dakwah sedekah YM dan juga Darul Quran. Lembaga ini bergerak pada tiga bidang utama, yakni pendidikan dan dakwah, bisnis dan usaha. Sedangkan dalam bidang sosial, Darul Quran Nusantara mendirikan PPPA Darul Quran yang secara khusus bertugas menghimpun dan mengelola dana sedekah (Daarul Qur'an, 2017). Genap pada usianya yang kesepuluh, terhitung sejak 5 April 2007 hingga 5 April 2017, PPPA telah berhasil menghimpun dana sebesar Rp. 671.352.623.502 dengan total donatur masuk sebanyak 68.519 orang. Sedangkan total khusus perolehan dana masuk dari terselenggaranya sedekah online (sejak 2015) sebesar Rp. 2.067.534.839 dengan jumlah total transaksi masuk sebanyak 10.677 transaksi (Thoriq, 2017). Hingga kini, penerima manfaat program telah mencapai 411 kabupaten di 34 provinsi serta tujuh negara. Semua sistem pelaporan terhadap sedekah terpusat ke PPPA Pusat yang terletak di Tangerang Jawa Barat (PPPA, 2017a).

\section{Sedekah Online}

Sedekah online yang terdapat dalam situs www.sedekahonline.com merupakan layanan sedekah yang diselenggarakan oleh PPPA Darul Quran sebagai wadah penampung dana sedekah. Tampilan utama (home page) situs sedekah online tersebut ditampilkan kutipan arti QS. al-Baqarah 272: 
"Dan apa saja harta yang baik yang kamu nafkahkan (di jalan Allah), maka pahalanya itu untuk kamu sendiri. Dan janganlah kamu membelanjakan sesuatu melainkan karena mencari keridaan Allah. Dan apa saja harta yang baik yang kamu nafkahkan, niscaya kamu akan diberi pahalanya dengan cukup sedang kamu sedikitpun tidak akan dianiaya (dirugikan)"

Selanjutnya di bawah kutipan ayat tersebut tersedia sebelas menu pilihan bagi para donatur untuk melakukan transaksi sedekah via online. Kesebelas program tersebut merupakan program nasional yang ditangani langsung oleh PPPA Darul Quran. Transaksi via online dapat langsung dikirim ke nomor rekening Yayasan Darul Quran Nusantara melalui: Bank Syariah Mandiri, Bank Muamalat, BNI Syariah, Mega Syariah, CIMB Niaga Syariah, Bank BTN, BRI, BCA, Mandiri. Sedangkan transaksi sedekah dapat menggunakan Kartu Kredit, Doku Wallet, ATM Transfer, maupun dengan bayar tunai melalui Teller Bank (PPPA, 2017b).

Dakwah sedekah YM tidak berhenti pada ceramah melalui media tradisional, namun juga disampaikan dengan menggunakan social media, khususnya Facebook dan Instagram. Hingga 27 Maret 2017, halaman Facebook YM telah disukai oleh sebanyak 6.966.300 audiens dan diikuti 6.900.399 audiens (Mansur, 2017). Sementara di media sosial Instagram, akun YM telah diikuti sebanyak 1.544.247 audiens (Mansur, 2017). Berdasarkan pengamatan peneliti dapat disimpulkan bahwa akun media sosial yang paling sering diperbarui oleh YM adalah Instagram dan Facebook. Sedangkan kontennya sebagian besar adalah seputar keseharian YM dan promosi program dari tim PPPA Pusat. Adapun kanal online, sebagaimana penjelasan dari direktur PPPA Yogyakarta yang digunakan sebagai sarana penunjang dakwah sedekah YM adalah www.sedekahonline.com, www.yusufmansur.com, www.pppa.co.id, www.daqu.or.id dan juga email sejutayusufmansur@gmail.com (Maulana, 2017).

\section{Otoritas Agama}

Otoritas keagamaan dapat diasumsikan ke dalam sejumlah bentuk dan fungsi, seperti kemampuan (kesempatan, kekuatan, atau kebenaran) dalam menentukan keyakinan dan praktek yang benar. Untuk membentuk dan mempengaruhi pandangan seseorang terhadap pemahaman sebelumnya (Krämer, Gudrun., 2006, hal. 1-6). Lebih lanjutnya, seorang agamawan dapat menggunakan legitimasi keagamaan melalui 
penafsiran serta pemberlakukan hukum Islam dalam menjalankan tugas mereka (Fauzia, 2016). Seiring hadirnya era new media dalam masyarakat beragama khususnya Islam, otoritas telah masuk ke dalam ruang-ruang online dengan melakukan penyesuaian pada fitur-fitur online. Champbell dalam artikelnya yang berjudul 'Who's Got the Power? Religious Authority and the Internet' memaparkan bahwa selama sepuluh tahun terakhir tema terkait hubungan agama dan online telah menjadi tren untuk diteliti (Campbell, 2017, hal. 1043-1062).

\section{Lapisan-Lapisan Otoritas}

\section{Self-Presentation (Presentasi Diri)}

Pada suatu perjumpaan seringkali masing-masing pihak melakukan usaha untuk mendefinisikan situasi. Dalam tahapan ini masing-masing pihak akan berusaha mengenal perilaku dengan cara memberikan pernyataan untuk membuat kesan seperti yang diinginkan oleh pemberi kesan. Konsep manajemen kesan seperti inilah yang disebut oleh Goffman sebagai the presentation of the self (Bullingham, Liam, 2013).

Manajemen kesan seperti itulah yang biasanya dikenal dengan dramaturgi. Dalam memahami teori ini seorang harus mengetahui terhadap keadaan yang yang terjadi pada front stage dan back stage. Hal ini berguna dalam melihat realitas yang terjadi di media sosial YM. Back stage adalah keadaan di belakang panggung dengan kondisi tanpa adanya audiens, sehingga sang aktor dapat bebas berperilaku tanpa memperhatikan perannya dalam sandiwara. Tetapi pertunjukkan dapat dimulai kembali ketika aktor penyampai pesan telah siap ke panggung pertunjukkan. Penampilan di depan audiens inilah yang disebut sebagai wilayah front stage. Adanya pertunjukkan adalah dalam rangka memberikan kesan positif kepada audiens dengan tujuan utama oleh seorang aktor yakni penerimaan audiens akan manipulasi kesan. Apabila sang aktor berhasil dalam memainkan perannya, maka aktor akan semakin mudah membawa audiens untuk mencapai tujuan daripada pertunjukkan tersebut. Seiring dengan berkembangnya teknologi new media, ruang presentasi diri juga mengikuti perkembangan media online. Artikel Bulingham dan Vasconcelos (Bullingham, Liam, 2013) yang mengamati bagaimana realitas online dibangun oleh aktor online setidaknya 
menjelaskan bahwa kerangka Goffman masih cukup relevan dalam mengamati interaksi yang terjadi pada dunia online dan offline. Bagian ini peneliti menganalisis penggunaan sumber tekstual guna memahami bahwa bahasa yang sekalipun tidak memiliki suara namun memiliki kekuatan yang dapat meyakinkan audiensnya.

Melalui media sosial, YM kerap menggunakan legitimasi agama sebagai penguat daripada pesan yang ia sampaikan kepada audiens. Hal ini tercermin dari beberapa status dan postingan dalam pembahasan yang terkait dengan sedekah. Seringkali pembaruan pada kedua media sosial secara langsung maupun tersirat didasarkan pada legitimasi al-Quran dan hadis serta bentuk pemahaman daripada kedua sumber primer umat Islam tersebut. Bahasa teks yang disampaikan oleh YM biasanya mengalami perpindahan dari penggunaan bahasa teks satu ke bahasa lain seperti yang telah disebutkan sebelumnya. Bentuk perpindahan tersebut adakalanya merupakan salah satu maupun beberapa kombinasi dari ketiganya. Seperti dalam postingan dalam situs miliknya yang biasa diposkan ulang pada akun Facebooknya secara rinci dapat dilihat pada Tabel 1.

Tabel 1 Isi postingan ulang pada akun Facebook YM

\begin{tabular}{ll}
\hline No & Isi postingan \\
\hline 1 & "If you need Allah... HE is in everywhere... HE is in anywhere." (Jika kau perlu kepada Allah, Dia \\
& ada dimanapun, Dia ada kapanpun). \\
& "Do more often whisper to Allah, God of this universe. Need something, need anything, find \\
& something, find anything, please talk to HIM. And the amazing thing, you can talk to HIM by your \\
& heart, your mind, your soul, your body... HE Can Listen all the way you talk." (Sering-seringlah \\
& berdoa kepada Allah, Tuhan semesta alam ini. Perlu sesuatu, butuh apapun, mendapati sesuatu, \\
& mendapatkan apa saja, tolong bicara dengan-Nya. Dan hal yang menakjubkan, Kamu bisa \\
& berbicara dengan Dia dengan hatimu, pikiranmu, jiwamu, tubuhmu... Dia Maha Mendengar atas \\
& segala hal yang kau ucapkan).
\end{tabular}

Status pada Tabel 1 berguna dalam membentuk keyakinan pembaca dengan mengarah pada segmen masyarakat tertentu, seperti halnya status ditujukan untuk orang-orang berpendidikan maupun kalangan menengah keatas. Memang dalam tulisan yang dimaksud terkadang tidak dijumpai secara langsung perihal sedekah, tetapi di dalam situs YM ketika membaca artikel apapun, pembaca secara langsung maupun tidak akan mendapati promosi terkait dengan sedekah online disertakan di sela-sela ruang web yang muncul dalam bentuk pop-up ketika mengklik status yang mengarah ke 
situs terkait. Jadi terlihat ada keterkaitan antara teks, penulis dan pembaca pesan. Hal ini merupakan faktor penting agar dakwah sedekah online dapat diterima dan masuk ke ruang ideologi pembaca sampai pada akhirnya diterjemahkan ke dalam bentuk tindakan nyata dengan ikut berpartisipasi pada kegiatan amal sedekah yang dipraktekkan dalam kehidupan sehari-hari (lifestyle). Menurut Webb Keane bahwa setiap karakter yang terkandung dalam bahasa teks memiliki kekuatan transendental dan memiliki pengaruh di dunia nyata (Keane, 1997, hal. 47-71).

\section{Switching Code (Kode Peralihan)}

Berkaitan dengan bahasa dan agama, kehadiran bahasa adalah jembatan bagi terbukanya jalan komunikasi antar sesama manusia, manusia dengan alam, serta manusia dengan Tuhan. Sedangkan konsep agama biasanya diasosiasikan dengan konsep Tuhan. Pengertian agama yang merujuk pada kata Inggrisnya, 'religion' di dalamnya termuat seluruh sistem tata nilai (aturan) untuk dijadikan sebagai pandangan hidup suatu kelompok masyarakat (Hidayat, 1997, hal. 73-75). Bahasa Indonesia sendiri mengartikan agama sebagai sebuah ajaran, sistem yang mengatur tata keimanan dan peribadatan kepada Tuhan serta tata aturan yang berhubungan dengan interaksi antar manusia dan lingkungannya. Membahas bahasa agama setidaknya dapat difokuskan ke dalam dua pengertian utama. Pertama, bahasa agama diartikan sebagai sabda Ilahi yang kemudian diabadikan dalam bentuk narasi teks kitab suci. Kedua, bahasa agama diartikan sebagai ungkapan serta perilaku keagamaan yang dilakukan oleh seorang maupun kelompok sosial. Bahasa agama dalam pengertian kedua inilah yang dapat diartikan sebagai wacana keagamaan yang dipraktikkan oleh umat beragama maupun seorang ahli agama. Tentunya, dalam hal ini, wacana keagamaan tidak terlepas dari bahasa teks yang dikonstruksi oleh orang yang dipandang sebagai ahli menafsirkan teks Ilahi (Kemdikbud, 2017).

Bentuk kode peralihan dapat diamati dari beberapa postingan YM di Instagram, salah satunya seperti ketika YM berbincang dengan seorang bapak tukang ojek di salah satu mushola SPBU yang dibuat seperti vlog singkat. Pada awal setelah YM menanyakan nama selanjutnya YM memberikan nasihat kepada bapak tersebut. Lebih jelas dapat dilihat pada Tabel 2. Status yang diunggah oleh YM pada Tabel 2 dapat dianalisis 
dengan memerhatikan kode peralihan serta bahasa agama. Seperti pada film transformer, sebuah film animasi fiksi ciptaan Hasbro yang sebelumnya telah populer di Indonesia terutama dikalangan anak-anak maupun para pecinta animasi. Film tersebut mengisahkan tentang autobots, yakni robot-robot yang dapat berubah secara cepat ke dalam bentuk menyesuaikan pada benda-benda di bumi seperti mobil, pesawat terbang, hewan, dan juga kaset.

YM mengajak pengikutnya di media sosial untuk bersedekah. Hal ini dapat dimaknai sebagai bentuk penguatan kepada audiens, setelah mereka diajak untuk berimajinasi kemudian dimasukkan ingatan untuk bersedekah. Dapat dimaknai juga bahwa YM tampak ingin mengajarkan kepada lawan bicara dan audiens di media sosial agar dalam setiap melakukan suatu pekerjaan senantiasa disertai dengan aktivitas ibadah, seperti halnya membaca selawat. Pembacaan selawat tersebut berguna dalam membentuk keyakinan pada diri audiens untuk melakukan amalan secara rutin. Adapun hal yang tidak terlewatkan, bahwa YM seringkali menyisipi atau mengakhiri dengan motivasi untuk bersedekah. Teks unggahan status YM (Tabel 2) memang membahas terkait motivasi untuk memiliki mental juara dan larangan miliki mental miskin.

Sekalipun kekuatan bahasa tidak terlihat, tetapi pada aspek tententu bahasa seolah memiliki kesan yang kuat dan mampu mendorong audiens untuk melakukan suatu tindakan seperti yang disampaikan oleh seorang yang diposisikan sebagai ahli dalam menafsirkan ajaran agama. Keduanya memiliki pengaruh yang penting untuk meyakinkan pembacanya. Peneliti menyimpulkan bahwa YM seringkali tampak menggunakan ragam bahasa serta menggunakan beberapa rujukan dari teks yang diambil dari al-Quran maupun hadis secara langsung ketika menyampaikan pesanpesannya terkait dengan sedekah online. Secara garis besar, bahasa yang sering digunakan YM berkutat pada tiga bahasa utama, yakni: Bahasa Indonesia, Bahasa Inggris dan Bahasa Arab secara lengkap dapat dilihat pada Tabel 3. Hal ini juga berlaku dari salah satu atau ketiga bentuk kombinasi maupun turunan dari bahasa tersebut. Penggunaan bahasa YM juga tergolong intens, namun dalam penggunaan bahasa Inggris seringkali terjadi seperti mengeja (spelling) dengan Bahasa Indonesia tekstual, sepertinya hal ini sekaligus untuk menguatkan konstruksi pesan bahwa pemakai bahasa 
adalah orang yang berpendidikan (Tabel 3). Seringkali, Bahasa Inggris tidak murni ditulis apa adanya, melainkan telah dimodifikasi YM sedemikian rupa. Hal ini oleh YM dijadikan alat untuk memudahkan komunikasi serta sebagai penguat otoritas bahwa si penyampai bahasa tidak hanya yang mengerti agama, juga berpendidikan karena melihat keumuman bahasa yang digunakan berstandar internasional sebagai alat komunikasi persinggungan antar budaya (Hadi, 2014, hal. 111-114).

Tabel 2 Skrip pada salah satu postingan Vlog YM

\begin{tabular}{|c|c|}
\hline Dialog & Makna \\
\hline $\begin{array}{l}\text { "Bilang sama Allah mau minta mobil mau minta } \\
\text { rumah pasti diberikan oleh Allah jika rajin-rajin } \\
\text { membaca selawat" } \\
\text { "Misal nih, kawan-kawan dorong gerobak, jagain } \\
\text { gerobak, ngelayanin orang, sambil selawat. Wuah, } \\
\text { tuh gerobak jadi transformer bertransformasi. Jadi } \\
\text { tujuh belas ruko dan puluhan kios. Jajal aja coba. } \\
\text { Jangan jajal sehari dua hari, tapi jajal betaon-taon. } \\
\text { Jajal keberkahan selawat. Apalagi dibarengi } \\
\text { dengan sedekah. top dah" }\end{array}$ & $\begin{array}{l}\text { Status tersebut dapat dijelaskan sebagaimana } \\
\text { berikut, bahwa kata yang tercetak tebal (selawat, } \\
\text { keberkahan, sedekah) adalah kata-kata yang } \\
\text { mengandung bahasa agama, sedangkan yang } \\
\text { tercetak italic (tujuh belas ruko, puluhan kios) } \\
\text { adalah balasan yang sifatnya lebih ke duniawi. } \\
\text { Sedangkan kata yang tercetak tebal plus miring } \\
\text { (transformer) adalah suatu kata ungkapan untuk } \\
\text { menggambarkan tentang begitu cepat dan dalam } \\
\text { bentuk yang tidak diduga sebagai balasan yang } \\
\text { akan didapat jika mengamalkan hal tersebut. }\end{array}$ \\
\hline
\end{tabular}

Tabel 3 Peralihan bahasa pada status YM di media sosial

\begin{tabular}{|c|c|}
\hline Status 1 & Status 2 \\
\hline $\begin{array}{l}\text { "Pagi saya (Indonesia) kejuted } \\
\text { (Indonesia+Inggris:ed), dikejutkan (Indonesia), } \\
\text { oleh (Indonesia) one of de bes (Inggris: one of the } \\
\text { best) tulisan (Indonesia). Kaming from awer femili } \\
\text { in (Inggris: Coming from our family in) Daqu } \\
\text { Jogja. Its (Inggris) judul (Indonesia) is veri } \\
\text { (Inggris: is very) keren (Indonesia). En ai think it's } \\
\text { laik has a soul. Has a spirit. Has a (Inggris: and I } \\
\text { think it's like has a soul. Has a spirit. Has a) jiwa } \\
\text { (Indonesia). Wen wi rid (Inggris: When we read), } \\
\text { faka-annamaa (Arab), bagaikan (Indonesia), } \\
\text { nahnu hunaaka (Arab), we are in de (Inggris: we } \\
\text { are in the) tulisan (Indonesia). We were der } \\
\text { (Inggris: We where there)... Makasih (Indonesia: } \\
\text { terima kasih) yaa Allah. Alhamdulillaah (Arab)...". }\end{array}$ & $\begin{array}{l}\text { "Dis is de (Inggris: This is the) tulisan } \\
\text { (Indonesia)...The (Inggris) Penulis (Indonesia) is in } \\
\text { my (Inggris) belakang (Indonesia)... The man is } \\
\text { (Inggris) Batik (Indonesia). Not Man in Black. In } \\
\text { Crown. (Inggris) Hehehe... Here is Part Two } \\
\text { (Inggris). Mantu (Indonesia)... Hahaha." }\end{array}$ \\
\hline
\end{tabular}




\section{Textual Reference (Referensi Tekstual)}

Ketika dihadapkan pada sebuah teks, setidaknya ada dua hal pokok yang perlu diperhatikan, yakni siapakah subjek yang berbicara dan obyek yang dituju. Disadari atau tidak bahwa ketika berhadapan dengan teks, di situ ada beberapa hal yang perlu diperhatikan, bahwa teks dan penulisnya saling terkait satu sama lain, tetapi jarang sekali keduanya hadir secara bersama-sama dihadapan pembaca. Maka, pada setiap pemahaman dan penafsiran teks, faktor subjektifitas pembaca menjadi sangat menentukan. Lebih jauh lagi, kegiatan membaca dan menafsirkan seperti halnya menulis ulang bahasa dalam bahasa pikiran seorang pembaca. Saat teks hadir di hadapan pembaca, maka teks dapat berbunyi dan berkomunikasi hanya ketika seorang melakukan aktivitas membacanya dan membangun makna berdasarkan pada sistem tanda. Kesimpulannya bahwa makna berada pada teks, pikiran pengarang, serta dalam penafsiran pembaca. Ketiga variabel itulah yang disebut oleh Komaruddin sebagai the world of the text, the world of the author and the world of the reader. Masing-masing dari ketiganya dapat berdiri sendiri tetapi saling terkait dan bisa juga sebaliknya (Hidayat, 1997).

Ada beberapa referensi berkenaan dianjurkannya sedekah dalam kehidupan seorang muslim. Beberapa sumber yang dijadikan acuan utama yakni al-Quran, hadis dan fatwa-fatwa ulama. Berdasarkan referensi teks dari beberapa penjelasan dalam kitab-kitab ahli hukum Islam, setidaknya terdapat pola kecenderungan dalam mengajak orang beramal sedekah lebih berorientasi pada dunia maupun materi. Hal ini berbeda dengan penjelasan para ahli hukum Islam yang mengajak atau memotivasi orang untuk bersedekah dengan orientasi mendapatkan pahala, keberkahan hidup, balasan kehidupan akhirat dan lainnya yang bersifat ukhrowi semata. Sedangkan aspek filosofis dalam sebuah pemberian hendaknya didasarkan pada beberapa tujuan utama, sebagaimana dijelaskan Badruzaman yang disarikan dari al-Quran dan hadis. Antara lain: Pemberian adalah dalam rangka mensucikan jiwa dari sifat kikir dan sebagai upaya untuk mendidik agar senantiasa berbagi. Hal inilah yang kemudian melekat dan menjadi karakter diri seorang muslim, sehingga bersedekah dapat menjadi kebiasaan (lifestyle). Selain itu juga sebagai wujud syukur atas nikmat Allah, mengobati hati dari cinta kepada dunia (materi semata), mengembangkan kekayaan batin (perasaan 
optimisme), menarik rasa simpati dan cinta, mensucikan harta (sedekah tidak mensucikan harta yang haram), juga mengembangkan dan memberkahkan harta (Badruzaman, 2016, hal. 32-35).

\section{Sedekah Online di Mata Audiens}

Pertemuan antara agama dan new media telah melahirkan fenomena baru yang terjadi di masyarakat. Agama dan media, merupakan unsur penting dalam melakukan studi lebih lanjut terkait dengan media sosial. Isu yang kerap diekspos dalam hubungan agama dalam wilayah virtual seperti ritual online, konstruksi identitas, serta mengubah pemahaman masyarakat. Sedangkan bentuk kewenangan merupakan bagian penting yang perlu dieskplorasi dalam mengkaji agama dan media sosial. Dikarenakan media sosial menyediakan ruang penting untuk mempelajari lapisan otoritas yang berkembang di masyarakat. Klasifikasi otoritas ke dalam beberapa lapisan adalah sebuah cara baru dalam memahami bentuk otoritas keagamaan yang terdapat di media sosial. Menurut Champbell bahwa untuk memahami otoritas secara lebih baik ada empat unsur, yaitu hierarki agama, struktur, ideologi dan teks. Tetapi dalam observasi ini untuk meneliti otoritas dengan lebih baik terfokus pada: self-presentation, switching code, dan textual reference. Ketiga lapisan otoritas tersebut digunakan untuk memahami otoritas keagamaan di ruang new media (Campbell, 2007).

\section{Persepsi Audiens Terhadap Sedekah Yusuf Mansur}

Informan yang bernama Yanto (48 tahun), seorang yang resign dari perusahaannya demi ingin melaksanakan ibadah tepat waktu. Bapak paruh baya ini sangat mengidolakan YM sejak beliau berceramah di televisi dan mengaku tertarik dengan buku-buku YM. Sekalipun sibuk tetap selalu meluangkan waktu membaca beberapa pembaruan status di media sosial YM. Mengikuti dakwah YM, menurutnya paling praktis melalui media sosial, karena dilakukan di sela-sela kesibukannya dapat membaca beberapa status YM. Bagi Yanto, YM merupakan sosok ustaz sekaligus motivator dalam hidupnya, sekalipun belum pernah bertatap muka secara langsung dengan YM, ia sangat yakin atas apa yang disampaikan oleh YM, terutama dalam motivasi sedekah yang disampaikan melalui media sosial. Setiap akan bersedekah, Yanto 
teringat dengan kata-kata YM. Ia sangat yakin bahwa apa yang disedekahkan akan dikembalikan oleh Allah dalam bentuk yang lebih baik. Kekaguman lain dari sosok YM adalah perjalanan hidupnya yang terlilit hutang kemudian dapat dilunasi karena amalan sedekah. Bagi Yanto perjalanan hidup YM itu menarik dan pantas untuk dijadikan pelajaran berharga untuk dirinya dan keluarga. Hal yang sering diperhatikan dari aktivitas online YM di media sosial adalah pada pembaruan status YM, ia menghindari konten seperti video karena konten dari video streaming YM kurang disukai, dengan alasan menyimak video membutuhkan waktu yang cukup lama padahal harus segera melakukan aktivitas yang lain (Yanto, 2017).

Febi (24), adalah sukarelawan salah satu lembaga sosial di daerah Yogyakarta. Ia mengenal YM sebagai ustaz sekaligus inspirator baginya dalam melakukan transaksi sedekah dan persoalan lain dalam menjalani kehidupan. Suatu ketika saat sepedanya hilang, kemudian berinisiatif untuk meniatkannya sebagai amal sedekah. Selang dua hari, sepeda tersebut kembali secara untuh tanpa kurang suatu apa pun dan seminggu kemudian mendapatkan hadiah motor dari bapaknya. Yakinnya pada saat itu, "sepeda kan dari Allah, kalau diminta oleh Allah maka ya sudah, tidak apa-apa”. Alhasil, dari adanya peristiwa itulah Febi semakin yakin bahwa barang siapa bersedekah akan mendapatkan balasan yang lebih besar dari apa yang disedekahkan. Sejak saat itulah, Febi semakin yakin terhadap apa yang dikatakan oleh YM dan sering teringat sosok YM setiap kali akan melakukan transaksi sedekah (Febi, 2017).

Nurul (29), seorang ibu rumah tangga dan juga salah satu pengikut YM di media sosial. Ketertarikan mengikuti YM di media sosial bermula mengikuti ceramah yang pernah disampaikan dalam beberapa kesempatan. Pada akhirnya ia memutuskan untuk bergabung dalam bisnis yang dikelola YM. Sejak saat itu, secara rutin mengikuti berbagai pembaruan YM di media sosial. Pada bisnis Paytren setiap transaksi dari penjualan produk ada yang namanya potongan keuntungan yaitu sebesar 2,88 persen per transaksi. Dana yang terkumpul dari jejaring bisnis tersebut disalurkan juga ke program-program sedekah YM. Baginya, potongan tersebut merupakan hal yang menyenangkan, karena secara tidak langsung telah ikut dalam kegiatan sedekah setiap kali bertransaksi (Nurul, 2017). 
Selanjutnya Ikhwan (24), seorang takmir paruh waktu yang bertugas di salah satu masjid di daerah Yogyakarta. Pembaruan di media sosial yang sering diingat dari sosok YM seperti nasihat tentang doa dan sedekah. Ia merasa tertarik dengan sosok YM sudah cukup lama dengan menunjukkan salah satu aplikasi sosial Telegram yang terdapat di komputernya, yang diberi nama YM Channel. Hal ini sebagai salah satu cara untuk berbagi rekaman ceramah maupun konten-konten YM dan menganggap hal ini bagian dari sedekah yang mampu dijalankan. Selain itu, ketertarikannya terhadap YM ditunjukkan dengan mengoleksi buku yang ditulis langsung oleh YM. Menurutnya YM adalah sosok ustaz yang asyik sekaligus menghibur, hanya bahasa teks yang disampaikan YM melalui pembaruan status di media sosial cenderung pada tema-tema tertentu. Ikhwan lebih menyukai ceramah YM dengan bertemu tatap muka secara langsung. Tetapi, lebih lanjut ia menegaskan, baik melalui offline maupun online keduanya tetap disukai. Menurutnya, apa yang YM sampaikan merupakan sebuah kebenaran yang tidak perlu diragukan. Dalam bersedekah, Ikhwan memang tidak secara khusus menyumbangkan sedekahnya melalui PPPA, tetapi dalam beberapa kesempatan ketika ada kelebihan rezeki ia tidak ragu mendermakan sebagian hartanya ke PPPA baik sedekah via online maupun offline (Ikhwan, 2017).

\section{Bahasa dan Gaya Bahasa Yusuf Mansur di Media Sosial}

Informan berikutnya adalah Putri (28), wanita karir paruh baya yang bekerja di salah satu lembaga filantropi. Ia sangat ingat bahwa ketika ingin sesuatu haruslah memperbanyak selawat dan sedekah. Keyakinan tersebut menjadi lebih mantap ketika ia melakukan amalan tersebut dan kemudian mendapatkan hasil yang berarti, maka secara ruitn ia mengamalkan apa yang disampaikan dan diajarkan oleh YM. Ia merupakan pengikut aktif YM di dua media sosial. Ketertarikannya terhadap gaya bahasa YM dalam mengomunikasikan pesan-pesannya di media sosial. Ia juga secara khusus mengoleksi ceramah-ceramah YM di laptopnya dan secara rutin rela menyisihkan uang untuk membeli dan mengoleksi buku-buku tulisan YM. Ia merasa nyaman dengan gaya bahasa YM, baik melalui tulisan pada buku maupun status yang rutin disimak melalui. Keyakinan tersebut menjadi lebih kuat lagi ketika ia memiliki kesempatan untuk berbincang dan bertatap muka secara langsung, ia mengaku bahwa hal tersebut ikut 
menguatkan keyakinan pada sosok YM. Kharisma yang dimiliki YM, masih dapat ia rasakan sekalipun melalui status atau pembaruan-pembaruan tulisan yang ia sampaikan melalui media sosial. Menurutnya gaya bahasa YM khas dan berbeda dengan yang lain sekalipun melalui media sosial (Putri, 2017). Sedangkan kesan Febi terhadap YM:

"Bahasanya kalau sama ustaz YM itu sedekah jor-joran. Punya mobil sedekahin, punya apa-apa sedekahin. Jadi, kalo sering kita ke mesjid kasih seribu, sama ustaz Yusuf kita dibilangin; jangan! jangan mas! masak untuk Allah kasihnya cuma seribu, kasihlah yang banyak."

Kata-kata itulah yang selalu ia ingat dari sosok sang ustaz. Ia mengaku bahwa awal mula dirinya tahu dan belajar tentang sedekah melalui status-status YM di media sosialnya. Baginya, sedekah memang harus dicoba dan dipaksakan supaya menjadi terbiasa sehingga menjadi bagian dari gaya hidup. Ia menyampaikan bahwa telah mengikuti tiga akun media sosial YM, seperti: Facebook, Instagram dan Twitter. Tetapi media sosial yang sering disimak setiap harinya, juga baca dan pelajari adalah akun YM yang ada di jejaring sosial Facebook dan Instagram. Kedua media sosial itulah yang secara rutin menjadi sarana bagi dirinya untuk belajar tentang sedekah. Febi sangat meyakini bahwa apa yang disampaikan oleh YM sepenuhnya adalah benar, sehingga setiap status maupun postingan di kedua media sosial tersebut pasti ia yakini dan ikuti. Bahkan ia menyampaikan, jika keyakinan tersebut diprosentasikan, maka rentang 90100 persen. Berbeda dengan Yanto, Febi tergolong cukup sering bertemu dengan YM, dan menjadi donator tetap di PPPA (Febi, 2017).

Sedangkan informan yang lain, Nurul menceritakan bahwa media sosial YM rutin ia ikuti setelah bergabung dalam bisnis Paytren milik YM. Adapun bahasa teks di media sosial yang ia ingat yakni:

"Ya semua kembali sama Allah, karena semua, apapun di dunia ini milik Allah. Mau kerja seberat apapun harus Allah yang diutamakan. Penuhi kewajiban kita dulu sama Allah, baru ikhtiar dhohir, mendoakan orang lain, mudahkan urusan orang lain. Semua itu pasti akan kembali kepada kita lagi segala kebaikan itu. Begitu juga dengan sedekah, pada hakikatnya melancarkan rejeki kita."

Gaya ceramah YM di media sosial cukup memberikan keyakinan bahwa bagi dirinya untuk ikut serta berpartisipasi dalam kegiatan amal sedekah. Ia berkata bahwa 
keyakinan pada sosok YM setelah ia mengikuti pembaruan di media sosial secara rutin ia berkeyakinan bahwa YM merupakan ustaz yang ia yakini bahwa apa yang disampaikan dalam postingan merupakan suatu kebenaran, meskipun sebelum mengikuti YM di media sosial, ia juga belajar dengan ustaz yang lain. Namun, penyampaian YM melalui media sosial lebih berkesan dalam penggunaan bahasanya dibanding ustaz yang lain. Hal inilah yang menambah keyakinan bagi dirinya untuk berbisnis sambil bersedekah (Nurul, 2017).

Penggunaan bahasa lain yang sering diingat oleh informan diantaranya seperti:

"Sedekah adalah solusi untuk segala hal" (Faizin, 2017). "Kalau pengen apaapa sedekah, kalau pengen apa-apa selawat" (Reda, 2017). "Mari bersedekah, setiap kita bersedekah maka Allah akan melipatgandakan rizki kita beberapa kali lipat" (Umayatun, 2017). "Sedekah jum'at pahalanya berlipat, yakin pada Allah, minta pada Allah, Allah maha kuasa atas hambaNya" (Rachmawati, 2017). "Jika kalian bersedekah seratus ribu maka Allah balas dengan sepuluh kali lipat, yak satu juta, subhanalloh" (Bagus, 2017).

Berdasarkan beberapa penjelasan para informan tersebut dapat ditarik pemahaman bahwa penggunaan bahasa agama seperti di atas cukup memberikan nilai kuat dalam menanamkan kesan agamis. Hal seperti inilah yang dikatakan oleh Keane (1997, hal. 47-71) sebagai bentuk legitimasi agama yang dapat mendorong audiens dalam ikut beramal sedekah.

\section{Sumber Rujukan yang disukai Audiens}

Reda (23), menurutnya YM adalah ustaz yang cocok dalam belajar ilmu tauhid, tetapi ketika akan belajar ilmu yang lain seperti ilmu mu'amalah dan fikih ia lebih senang merujuk pada ustaz lain. Reda menyampaikan, "kalau pengen apa-apa, ya sedekah, kalau pengen sesuatu selawatin aja"

Mualifin (22), audiens YM di media sosial. Menurutnya, YM merupakan ustaz yang lebih cenderung pada salah satu aliran keislaman dan memperhatikan amalanamalan yang direkomendasikan kepada jamaahnya merupakan amalan-amalan yang lebih condong pada model keislaman ala Nahdhatul Ulama. Tetapi terlepas dari itu, YM merupakan sosok ustaz yang memberikan motivasi, nasihat-nasihat dan memiliki peran 
yang selalu ditunggu masyarakat. Hal yang selalu diingat Mualif terhadap YM adalah ustaz sedekah, ustaz yang ingin merangkul semua golongan Islam.

Pada awalnya, secara ruitn Mualif mengikuti akun YM, namun seiring dengan kesibukan, akun YM menjadi jarang diikuti di media sosial. Mualif berkeyakinan bahwa YM adalah sosok yang cukup bagus untuk diikuti ketika ingin belajar ilmu tauhid, sedangkan saat belajar ilmu lain, beralih dengan ustaz lain. Model keislaman YM sangat berbeda dengan dengan yang dipelajari, karena Mualif sedang belajar tentang Islam salafi. Tetapi berkaitan dengan sedekah, ia masih rutin mengikuti bersedekah di salah satu lembaga PPPA, baik secara offline maupun beberapa pengajian yang dapat diikuti. Menurutnya, dakwah YM dulu lebih mengedepankan semua persoalan dapat diselesaikan dengan sedekah, tetapi sekarang YM lebih melihat pada perkembangan permasalahan yang dihadapi masyarakat Islam (Mualifin, 2017). Informasi dari para audiens, bahwa pengikut YM di media social berasal dari berbagai latar belakang yang berbeda dengan motivasi yang berbeda. YM tergolong agamawan yang cukup banyak diikuti uamt Islam di Indonesia. Tercatat bahwa untuk ukuran seorang ustaz jumlah audiens YM terbanyak dibanding ustaz-ustaz yang lain di media sosial. Dengan potensi yang demikian itulah dakwah dapat menjangkau audiens dengan jumlah lebih banyak.

Hasil wawancara terhadap sebelas audiens dengan memperhatikan latar belakang, posisi sosial, serta usia informan yang berbeda menunjukkan bahwa bahasa teks dalam dakwah sedekah online YM masih cukup relevan dalam memotivasi umat Islam untuk bersedekah. Artikel ini memberikan gambaran bahwa media sosial memiliki potensi dalam menegaskan dan mengubah persepsi masyarakat terhadap konsep yang dipahami sebelumnya berkaitan dengan sedekah. Hal ini sesuai dengan apa yang disampaikan Campbell (Campbell, 2017). Selain itu, fakta lapangan juga sesuai terhadap apa yang disampaikan Hidayat (1997, hal. 73-75) bahwa efektivitas bahasa tulisan bergantung pada keterhubungan antara tulisan (the world of the text), penulis (the world of the author) dan pembaca (the world of the reader). Hal ini diketahui dari hasil wawancara terhadap informan yang memiliki ideologi berbeda dengan penulis teks (YM). YM juga tidak memiliki pengaruh berarti terhadap keharusan audiens untuk mendermakan harta ke lembaga sosial filantropi PPPA. Meskipun demikian, sosok YM dengan gaya bahasanya di media sosial masih memegang peranan cukup penting dalam 
otoritasnya sebagai ustaz untuk diikuti di ruang offline. Hal ini setidaknya berlaku bagi audiens yang belum secara kuat berafiliasi dengan golongan Islam tertentu. Sedangkan terhadap orang yang memiliki ideologi keislaman yang berbeda, otoritas YM tidak memiliki pengaruh yang signifikan untuk diikuti.

\section{Simpulan}

Memahami otoritas Yusuf Mansur dalam sedekah online, setidaknya ada tiga lapisan otoritas yang perlu diperhatikan, yakni self-presentation (presentasi diri), switching code (kode peralihan) dan textual reference (referensi tekstual). Selfpresentation yang diperankan oleh YM yakni dengan mengkonstruksi dirinya sebagai seorang ustaz, selalu berpikiran positif, selalu mengetahui informasi terbaru dan lain sebagainya. Selain itu juga, cara mempertahankan diri diruang online terlihat bahwa YM seringkali menyampaikan dakwahnya secara langsung untuk menghindari adanya manipulasi pesan dalam bentuk meme dan tulisan dalam status Facebook seringkali disertakan link ke web resminya. Sedangkan dalam mempertahankan kesan positif, ketika ada komentar dari audiens yang sifatnya menyanggah atas argumennya pada pembaruan pos di Instagram, maka YM menunjukkan komentar tersebut dan diunggah ke akun pribadinya untuk selanjutnya disertakan komentar dari YM. Hal ini dapat dipahami sebagai upaya dari YM dalam mempertahankan dirinya diruang virtual.

Textual reference dalam beberapa status maupun tulisan YM terdapat pembaruan status dengan menyertakan sumber pokok Islam berupa teks dari al-Quran dan hadis. Pola dalam merujuk teks terlihat seperti penafsiran ulang pada teks yang kurang sesuai dengan argumennya serta sesekali menampilkan potongan surat maupun ayat. Tindakan mengutip ayat tersebut dapat dimaknai sebagai upaya untuk menguatkan legitimasi dalam pesan dakwah. Artikel ini menunjukkan bahwa dakwah sedekah YM disampaikan dengan bertumpu pada lapisan otoritas: self-presentation, switching code, dan textual reference. Ketiga hal tersebut berguna untuk menguatkan legitimasi pesan dakwah sedekah online YM serta sebagai upaya untuk mempertahankan diri di media sosial. Sedangkan pesan dakwah lebih banyak dikomunikasikan dengan mengaitkan pada imbalan materi. Upaya tersebut dapat menguatkan keyakinan audiens dalam bersedekah, tetapi audiens dengan ideologi yang berbeda memiliki kecenderungan selektif dalam menerima pesan. 


\section{Referensi}

Abidin, H. (2013). Membangun Akuntabilitas Filantropi Media Massa. Depok: Piramedia.

Adelman, C. C. (2003). Development Assistance Committee: Philanthropic Foundations and Development Co-operation.

APJII. (2016). Infografis Penetrasi dan Perilaku Pengguna Internet Indonesia.

Azzam, Abdul Aziz Muhammad, \& A. W. S. H. (2010). Fiqih Ibadah. Jakarta: Amzah.

Badruzaman. (2016). Aspek-Aspek Filosofis Zakat dalam Al-Qur'an dan As-Sunnah. Asas: Jurnal Hukum dan Ekomomi Islam, 8(1), 30-36.

Bagus. (2017). Wawancara dengan Audiens Media Sosial Yusuf Mansur.

Barton, David, \& C. L. (2013). Language Online: Investigating Digital Texts and Practices. New York: Routledge.

Baznas. (2016). Baznas Siapkan Strategi Zakat.

Bullingham, Liam, \& A. C. V. (2013). The Presentation of Self in the Online World': Goffman and the Study of Online Identities. Journal of Information Science, 39 nomer 1 .

CAF. (n.d.). World Giving Index.

Campbell, H. (2007). Who's Got the Power? Religious Authority and the Internet. Journal of Computer: Mediated Communication, Nomer 12.

Campbell, H. (2017). Who's Got the Power? Religious Authority and the Internet. Journal of Computer: Mediated Communication, 12.

Daarul Qur'an. (2017). Profil Daarul Qur'an.

Faizin. (2017). Wawancara dengan Audiens Media Sosial Yusuf Mansur.

Fauzia, A. (2016). Filantropi Islam: Sejarah Kontestasi Masyarakat Sipil dan Negara Indonesia. Yogyakarata: Gading Publishing.

Febi. (2017). Wawancara dengan Audiens Media Sosial Yusuf Mansur.

Hadi, N. (2014). The 1st Academic Symposium on Integrating Knowledge: The 1st ASIK. Johor-Malaysia: Universiti Teknologi Malaysia. 
Hasan, N. (2009). The making of public Islam: Piety, agency, and commodification on the landscape of the Indonesian public sphere. Contemporary Islam, 3(3), 229-250. http://doi.org/10.1007/s11562-009-0096-9

Hidayat, K. (1997). Memahami Bahasa Agama: Sebuah Kajian Hermeneutik. Jakarta: Paramadina.

Ikhwan. (2017). Wawancara dengan Audiens Media Sosial Yusuf Mansur.

Ipsos. (2017). Views on Globalisation and Faith Latest Findings from the Ipsos Global @advisor survey.

Jakarta, D. S. P. U. S. H. (n.d.). Merayakan Kedermawanan Muslim.

Keane, W. (1997). Religious Language. Annual Review Anthropology, 26, 47-71.

Kemdikbud. (2017). Kamus Besar Bahasa Indonesia.

Kepresidenan, K. S. (n.d.). Potensi Zakat di Indonesia Sangat Besar.

Krämer, Gudrun., \& S. S. (2006). Speaking for Islam: Religious Authorities in Muslim Societies. Leiden-Boston: Brill.

Latief, H. (2017). Transforming the Culture of Giving in Indonesia : The Muslim Middle Class, Crisis and Philanthropy *.

Mansur, Y. (2017). Observasi pada Akun Facebook Yusuf Mansur.

Mansur, Y. (2017). Observasi pada Akun Instagram Yusuf Mansur.

Maulana. (2017). Wawancara dengan Audiens Media Sosial Yusuf Mansur.

Mualifin. (2017). Wawancara dengan Audiens Media Sosial Yusuf Mansur.

Muslim, G. (n.d.). Indonesia Tempati Peringkat Ke-3 Dunia dari 6.393.464 Visa Umrah yang Diterbitkan Tahun Ini.

Nurul. (2017). Wawancara dengan Audiens Media Sosial Yusuf Mansur.

PPPA. (2017a). Milad dan Public Expose 10 Tahun PPPA Daarul Qur’an, 2017(April).

PPPA. (2017b). Sedekah Online.

Putri. (2017). Wawancara dengan Audiens Media Sosial Yusuf Mansur.

Qardhawi, Y. (2013). Shadaqah: Cara Islam mengentaskan Kemiskinan. Bandung: PT Remaja Rosdakarya. 
Rachmawati. (2017). Wawancara dengan Audiens Media Sosial Yusuf Mansur.

Reda. (2017). Wawancara dengan Audiens Media Sosial Yusuf Mansur.

RI, K. (2014). Kamus Istilah Keagamaan. Jakarta: Puslitbang Lektur dan Khazanah Keagamaan.

Thoriq. (2017). Wawancara dengan Pengurus PPPA Pusat Bagian Keuangan via WhatsApp. Yogyakarta.

Umayatun. (2017). Wawancara dengan Audiens Media Sosial Yusuf Mansur.

Walters, P. (2017). Facebook "Likes" for Social Good.

Yanto. (2017). Wawancara dengan Audiens Media Sosial Yusuf Mansur.

Yayan, M. A. F. (2013). Kun Yusuf Mansur: Kisah Perjalanan Hidup Ustadz Yusuf Mansur. Jakarta: Erlangga. 